\title{
Study on the Usage of Multimedia Technology in Music Theory Teaching
}

\author{
Tian Wen \\ Shandong University Of Arts (China Shandong 250300)
}

Keywords: Multimedia technology; Music theory teaching; Application

\begin{abstract}
With the deepening development of new curriculum reform, the application of multimedia technology in music theory teaching has become more and more frequent. With the current situation of application of multimedia technology in teaching, this study analyzes the function of multimedia in enhancing the teaching efficiency of music theory, then introduces the advantage and value of multimedia technology applied in music theory classroom teaching. Finally, this paper combines the above contents and makes judgement on teaching strategies and application of multimedia technology, but also hopes for that the multimedia technology can be better applied to create conditions for music theory teaching .

Multimedia teaching refers to the teaching mode through the multimedia platform and equipment. With the rapid development of information technology and the continuous improvement of economic development in our country, the application of multimedia technology in music classroom teaching at all stages has become more and more widespread. From the objective point of view, multimedia technology not only has a more attractive, but also can create effects of atmosphere, which stimulates students' enthusiasm for learning and maintains students' learning enthusiasm. In order to further analyze the role of multimedia technology in the teaching of music theory courses, this paper introduces the role of multimedia technology in enhancing the efficiency of music theory teaching courses.
\end{abstract}

\section{Part One Multimedia Technology can Improve the Efficiency of Music Theory Teaching}

In the traditional framework of teaching mode, teachers only need a piano and a tape recorder to complete all the teaching tasks. However, with the continuous development of the times, the current multimedia technology has become more and more mature. Through the effective integration of multimedia technology, people not only break through the limitation of time and space, but also provide students with a more intuitive channel for understanding the value and charm of music, and the values of enhancing the efficiency of music theory teaching mainly lie in the following two aspects:

\section{Enhancing the Intuitive of Theory Teaching}

In the music theory teaching activities, many words and theories have a strong abstraction which leads to many students who are in the process of learning can not grasp the essence of knowledge. From the perspective of teaching acceptance, the teaching of music theory is as difficult as any other science and engineering subjects. With the continuous development of multimedia technology, the powerful features of infectivity, vividness and reproducibility in multimedia teaching are gradually emerging. It not only can arouse students' interest and attention, but also can better help students to grasp new knowledge and understand the new environment. Under the traditional teaching mode, the development of music history and the development form of art subjects often make people feel dull and boring, and with strong abstractness, even the teacher's explanation will be more laborious not to mention the acceptance ability of students. Through the integration of multimedia technology, teachers can play a variety of ancient musical instruments through the video, and they can play the scene of modern symphony venue directly to make the students feel the differences between Chinese and Western culture and the differences between of modern art and ancient art, so as to let the students have a more comprehensive understanding of the system to process the change and development of things. In addition, in the music theory teaching, multimedia teaching can fully reflect the value of teaching music theory which includes music information, history and local customs which can be conducted to show through multimedia, and 
this can not only let the students feel be in the air, but also can stimulate the students' learning enthusiasm and cause resonance to create the conditions for the better understanding of the beauty of the music.

\section{Improving the Richness of Music Theory Teaching}

In music theory teaching activities, the another advantage of multimedia technology is to create vivid teaching situations for students, which has a certain role in promoting students integrate into classroom atmosphere. In the process of designing teaching goal, teaching workers want students to master knowledge and skills, and hope that their comprehensive core competence can be effectively promoted, while this part can not be realized by traditional teaching mode. In teaching, playing some excellent music videos through multimedia and playing some famous fragments at all times and in all over the world can cultivate students' musical accomplishment and exert a subtle positive influence on their appreciation ability. In addition, as a kind of auditory art, music is weaker than visual in overall visualization. Therefore, it is necessary to combine visual and audio education skillfully through multimedia technology so as to further enhance the teaching effect. For example, in the teaching of the works of some famous Western musicians, teachers can play some of the musicians 'biographies and documentaries so that students can have a general understanding of the musicians' life experiences and then experience and feel the music itself, and this way can lead students to feel the writer's thoughts and emotions in different stages of creation and have a good effect on understanding the value of music.

\section{Part Two The Characteristics of Multimedia Technology Applied in the Music Theory Classroom Teaching}

\section{Motivating Students' Interest in Learning}

Multimedia teaching methods have a wealth of teaching adaptability and good teaching image, which can give students a deep impression of learning. In addition, multimedia technology can enhance teaching effectiveness by enhancing students' level of understanding of musical theory. From the nature of music appreciation, it is an art form of listening to emotions by itself. Therefore, by combining listening, watching and thinking in multimedia teaching, teachers can not only create more perfect educational situations, but also stimulate the aesthetic taste of students through the role of synaesthesia. In addition, in a relaxed and happy environment students are also more likely to learn and recognize the fun of learning music, and then take the initiative to experience, perceive and experience a variety of musical works. Novel and unique art forms and rich images will also stimulate the sparks of students' emotions, so they will take the initiative to put into teaching activities. In addition, multimedia technology has a positive effect on promoting better teacher-student relationship and forming a good cooperation model.

\section{Enriching Students' Imagination}

Rich imagination is one of the important goals of music teaching, which is also one of the basic goals of education. In teaching activities, students can experience the value of music theory by integrating audiovisual images and texts from different perspectives. By integrating the boring language and rich video images indirectly, the teaching effectiveness can be multiplied. With the use of multimedia teaching, it also can make the complexity of the image become simple, and through the audio and video to show works to students, it can expand their space for imagination and form a unique field of art, which is obviously important to stimulate their imagination.

\section{Part Three Strategy of Using Multimedia Technology Applied in Music Theory Teaching}

The application of multimedia technology in theoretical teaching has a good advantage, but this does not mean that teachers can easily complete the teaching task and achieve the teaching goal by simply imitating. According to the application of current multimedia technology in music theory courses, most teachers are not familiar with the production of courseware, and they are not yet ripe for the actual choice of multimedia teaching. In order to further enhance the pertinence of teaching, teachers must attach importance to the following two specific aspects of the work. 


\section{Taking Emphasis on the Application of Multimedia Technology in Classroom Teaching}

Multimedia technology has a strong intuitive, it can well attract the attention of students so as to achieve good teaching results. However, some teachers make excessive use of multimedia in the teaching process which results in the immersion of students in multimedia videos and animations. After the class, teachers find that students have not remembered anything, which reduces the effectiveness of theoretical teaching. In addition, some teachers often mistakenly teach some simple teaching links through the multimedia complication, and this way can not improve teaching efficiency, and it has also affected the overall time in the classroom which reduces students' enough space to imagine and enhance, and this is not in line with the original intention of teaching.In response to the above problems, in addition to further enhance the teaching ability of teachers and training teaching experience, teachers also should pay attention to the choice of the timing of the application of multimedia technology, and it is necessary to ensure that students' motivation to learn to ensure the effectiveness of teaching as well as the basic characteristics of the knowledge of the class. Otherwise, there will be overwhelming situation, which will can not highlight the value of teaching and don't make good use of multimedia technology to affect the teaching effectiveness and delay the valuable classroom time of students.

Paying Attention to the Originality and Pertinence of Courseware

In the choice of courseware, some teachers tend to choose some more fixed courseware for teaching, and the advantage is that the teaching mode is relatively stable and not prone to problems, but it will also limit the teacher's own play, which requires teachers must be conducted in accordance with the courseware of others teaching. With the continuous development of the times, students' requirements for the quality of courseware are also constantly improving. In addition to mastering some multimedia teaching ability, teachers should learn how to make various courseware and make courseware by learning to improve the originality of courseware, and teachers also can improve the relevance of courseware. In the process of teaching, different classes and different students have different levels of understanding and mastery of the theory of music theory. By designing courseware by themselves, teachers can better grasp the progress of classroom teaching so as to be able to match better with the students' learning stage to achieve the value and role of multimedia technology in theoretical teaching.

\section{Conclusion}

In summary, the application of multimedia technology in the music theory teaching has its real value and significance, which not only can effectively stimulate students' enthusiasm for learning, but also convey the charm of music more directly to the students so that students can truly recognize the fun of learning music so as to enhance the learning effect. Based on the situation and problems of multimedia technology in the music theory teaching, in addition to emphasizing the application of multimedia technology in the classroom teaching, it is also necessary to attach importance to the originality and pertinence of courseware. By constantly innovating teaching modes, making full use of teaching resources, it can realize the overall improvement of teaching level.

\section{References}

[1] Zhenqi Li. Practical research on multimedia technology in music theory teaching[J].The Sound of the Yellow River,2015(21): 18.

[2] Yingji Jin. The role of multimedia in the teaching of music technology theory[J].Brand (Theory Version), 2010(10):75-76.

[3] Di Ma. The application of multimedia technology in music teaching[J].Chinese Adult Education,2008(13):182.

[4] Yi Wan. The situation and existing problems of using multimedia in music teaching[J].Education Practice and Research (Primary Edition),2007(12):54-55.

[5] Yong Zhao. Study on the making of music courseware and multimedia[J].Reading and writing (Education Teaching),2007(09):99. 